\title{
Topical Calcineurin Inhibitors and Lymphoma Risk: Evidence Update with Implications for Daily Practice
}

\author{
Elaine C. Siegfried $\cdot$ Jennifer C. Jaworski • \\ Adelaide A. Hebert
}

Published online: 24 May 2013

(c) The Author(s) 2013. This article is published with open access at Springerlink.com

\begin{abstract}
Topical calcineurin inhibitors (TCIs), commercially available since 2000-2001, are the first and only topical medications approved for chronic treatment of atopic dermatitis $(\mathrm{AD})$ in pediatric patients and remain a welcomed alternative to topical corticosteroids. In January 2006, the US Food and Drug Administration (FDA) issued a boxed warning requirement based on a theoretical risk of malignancy (including lymphoma) with TCI use. However, in the years since, analyses of epidemiologic and clinical data have failed to demonstrate a causal relationship between TCI use and malignancy or lymphoma risk, especially for pimecrolimus cream. In fact, the observed number of malignancies and lymphomas observed both in post-marketing surveillance and reported to the FDA using its adverse events reporting system is much lower among TCI-exposed patients than the expected number for the general population. Furthermore, among children enrolled in post-marketing pediatric registry studies for both tacrolimus and pimecrolimus followed for up to 5.5 years $[10,724$ patient-years (PY)] or 6.5 years $(16,219 \mathrm{PY})$, respectively, the observed number of malignancies and lymphomas is very low and similar to the number expected for a sample of similar size in the general population. In addition to reporting these comparative malignancy and
\end{abstract}

E. C. Siegfried ( $\square)$

Saint Louis University and Cardinal Glennon Children's

Hospital, 1465 S Grand Ave., St. Louis, MO 63104, USA

e-mail: esiegfri@slu.edu

J. C. Jaworski

Prescott Medical Communications Group, Chicago, IL, USA

A. A. Hebert

University of Texas Medical School at Houston,

Houston, TX, USA lymphoma data, this article provides a historical overview of the boxed warning requirement and critically evaluates the preclinical, clinical, and epidemiological evidence that has thus far failed to substantiate a relationship between TCI use and malignancy. The authors also provide practical clinical advice for optimizing AD management and patient care in the context of the boxed warning.

\section{Introduction}

Topical tacrolimus ointment and pimecrolimus cream have been commercially available for more than a decade and are the first and only drugs approved for chronic treatment of atopic dermatitis (AD) in pediatric patients. These topical calcineurin inhibitors (TCIs) have been a welcomed alternative to topical corticosteroids because their chronic use is not associated with skin barrier compromise or increasing percutaneous absorption. However, in January 2006, the US Food and Drug Administration (FDA) instituted a boxed warning for both TCIs based on a theoretical risk of malignancy (including lymphomas) that sparked an ongoing debate over the safety of these drugs. Since then, despite a number of epidemiological and clinical studies, no clear link between TCI use and lymphoma risk has been established. Yet, the boxed warning remains, leaving many physicians hesitant to prescribe TCIs and countless patients (including infants and children) exposed to other antiinflammatory agents with proven adverse effects. This review will (1) present a historical overview of the basis for the boxed warning, (2) review and critically evaluate the evidence for lymphoma risk, (3) provide practical clinical and evidence-based advice on using TCIs in the management of $\mathrm{AD}$, and (4) offer advice on addressing obstacles to patient access to these drugs. 


\section{Background}

\subsection{Regulatory History of the Boxed Warning for TCIs}

Tacrolimus ointment 0.03 and $0.1 \%$ [Protopic $^{\circledR}$; owned and developed by Fujisawa (now Astellas)] and pimecrolimus cream $1 \%$ (Elidel $^{\circledR}$; developed by Novartis, Meda acquired global rights to Elidel ${ }^{\circledR}$ in 2011 and immediately licensed North American rights to Valeant) are TCIs, which inhibit transcription and release of inflammatory cytokines and mediators from $\mathrm{T}$ cells [1]. In December 2000, tacrolimus ointment was approved for "short-term and intermittent long-term therapy in the treatment of patients ( $\geq 2$ years of age) with moderate to severe AD in whom the use of alternative, conventional therapies is deemed inadvisable because of potential risks, or in the treatment of patients who are not adequately responsive to or are intolerant of alternative, conventional therapies" [2]. At that time, no efficacy or safety studies had been conducted with tacrolimus in infants, and the approved indication was limited to patients at least 2 years of age. One year later, in December 2001, pimecrolimus cream was approved with a similar indication for mild-to-moderate $\mathrm{AD}$ with similar warnings and contraindications based on pharmacological class [3]. In contrast to tacrolimus, data demonstrating the safety and efficacy of pimecrolimus were available at the time of application for 436 infants who had participated in clinical trials. On the basis of the "disproportionately higher incidence of adverse events, particularly viral infections in infants," seen in these trials, the approved indication was limited to patients 2 years of age and older. To further investigate the long-term safety of both drugs, the FDA requested post-approval commitments from both companies to establish pediatric registries $[4,5]$.

At the time of drug approval, the FDA requested that Astellas perform additional studies of topical tacrolimus including: a retrospective analysis to explore any demographic and disease factors possibly associated with persistently detectable blood concentrations [6]; bioavailability of 0.03 and $0.1 \%$ ointments following long-term intermittent treatment of $\mathrm{AD}$ [7]; and pharmacokinetics of $0.03 \%$ ointment in patients $2-5$ years of age with moderate-to-severe $\mathrm{AD}[7]$.

Upon pimecrolimus cream approval, the FDA also requested that Novartis conduct two case-control epidemiological studies to assess the risk of non-melanoma [8] and melanoma skin cancers (protocol under FDA review) in adults; a controlled safety and efficacy study in HIVpositive patients; and a pregnancy registry. The last two requests were waived/fulfilled via labeling change or provision of additional preclinical data. In addition, Novartis initiated two ambitious long-term randomized clinical studies to assess the effects of pimecrolimus cream in infants as young as 3 months of age: a 6-year study $(N=1,091)$ designed to evaluate long-term safety and the impact of AD treatment on the progression of atopy; and a 5-year study $(N=2,418)$ designed to evaluate long-term safety including growth velocity and immune system development effects [9-13].

In October 2003, the FDA Pediatric Advisory Committee (PAC) met to review the products' registry protocols. However, the focus of the meeting was shifted by recognition of increasing off-label use among infants younger than 2 years of age ( $11 \%$ of all TCI prescriptions by the end of 2003; Fig. 1) [14] as well as by malignancy reports made to the FDA's adverse event reporting system (AERS): two reports for pimecrolimus cream and five for tacrolimus ointment. Following this meeting, two 10-year prospective registries (planned $N=8,000$ for each) were created to assess the risk of malignancies in children with tacrolimus ointment [A Prospective Pediatric Longitudinal Evaluation to Assess the Long-Term Safety (APPLES) of tacrolimus ointment for the treatment of AD] and pimecrolimus cream [Pediatric Eczema Elective Registry (PEER)]. APPLES includes patients no older than 16 years of age and was initiated in 2005; PEER includes patients 2-17 years of age and was initiated in 2004.

The PAC convened 15 months later in February 2005 to review the results of a newly completed oral carcinogenicity study conducted in monkeys (the results of which are discussed in detail in Sect. 3.1) as well as additional AERS malignancy reports. The concerns of the PAC were elevated in part by the manufacturers' marketing efforts, escalating TCI sales, and a higher rate of off-label use. On the basis of the recommendation made at this meeting, the FDA issued a public health advisory in March 2005 and a requirement in January 2006 for revised labeling for both products to include a boxed warning ('black box') and medication guide ('patient medi guide') to address a theoretical risk of lymphoma and to emphasize that the safety of long-term continuous use and use in patients 2 years of age and younger had not been established $[14,15]$. In addition, the indications were modified to specify that TCIs are "second-line [emphasis added] therapy for short-term and non-continuous chronic treatment... of [AD] in nonimmunocompromised adults and children [ $\geq 2$ years of age] who have failed to respond adequately to other topical prescription treatments, or when those treatments are not advisable" $[3,16]$. This was the first time that the FDA required that a boxed warning be issued on the basis of a theoretical risk rather than proven safety concerns.

At subsequent meetings held in March 2010 and May 2011, the PAC reviewed post-marketing surveillance (PMS) and epidemiological data for both drugs and found it to be inconclusive with regards to both long-term safety 


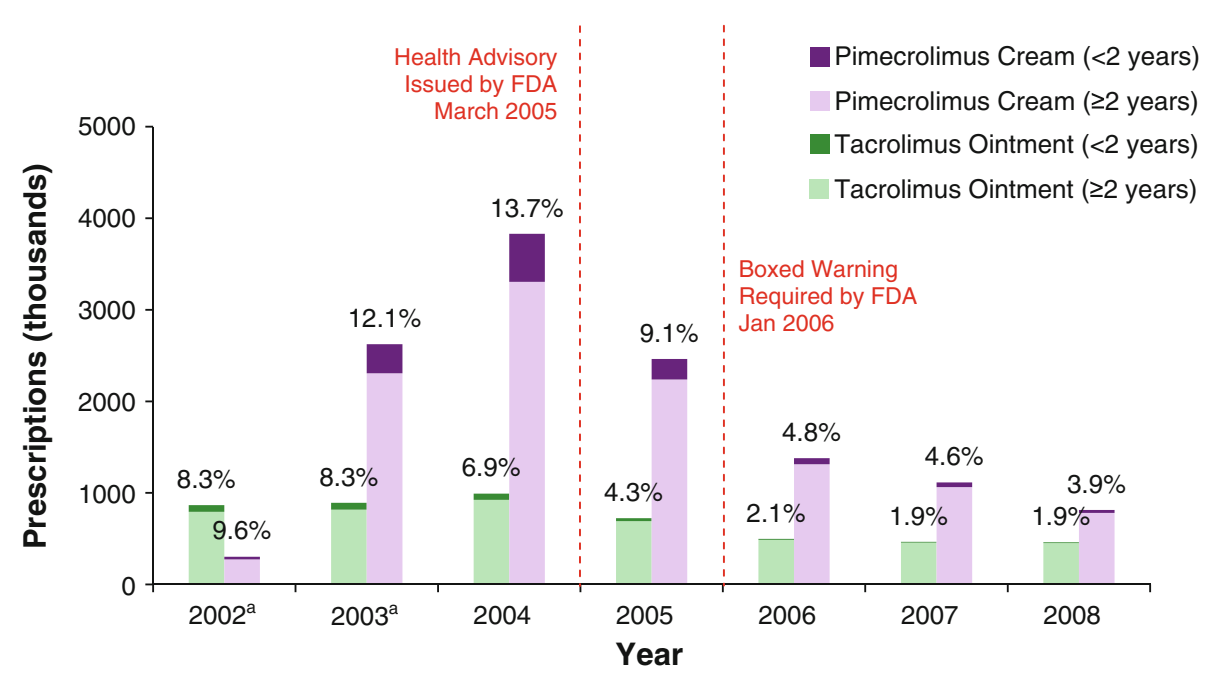

Fig. 1 US pimecrolimus cream and tacrolimus ointment prescriptions (2002-2008). Interval for each year is January 1-December 31 except where noted. Values are percent of prescriptions dispensed for infants $(<2$ years of age). Data source (2004-2008): SDI Vector One ${ }^{\circledR}$ National in briefing document from Patty Greene, Drug Use Data Analyst, Division of Epidemiology, Office of Surveillance and Epidemiology, FDA Center for Drug Evaluation and Research. BPCA drug use review: Comparison of Elidel $^{\circledR}$ cream and Protopic ${ }^{\circledR}$ ointment utilization trends following 2006 labeling changes, 17 July 2009. Available from http://www.fda.gov/downloads/AdvisoryCom

concerns and malignancy risk $[17,18]$. At both meetings, the committee requested that the FDA continue to monitor the literature, AERS, and product registries and maintain the boxed warning until conclusive evidence was found [18]. In light of these inconclusive findings, this re-examination of a possible link between TCI use and lymphoma was undertaken.

\subsection{Response from the Public and the Medical Community}

News coverage of the boxed warnings was widespread, with stories appearing in notable publications, including USA Today [19], Washington Post [20], BBC News [21], and Consumer Reports [22]. The resulting patient concerns led some patients and caregivers to dispose of their TCIs and opt for other treatments or forgo treatment altogether. Law firms began posting websites dedicated to soliciting litigations against the makers of TCIs [23-27], further adding to the anxiety among patients and caregivers.

Members of the medical community criticized the FDA's action and suggested that an unintended result was to jeopardize the chances of ever clarifying the risks due to decreased participation in clinical trials [28]. Some argued that the FDA did not fairly weigh the data with respect to low systemic exposure seen in humans, lack of cancer adverse events in clinical studies, overall low rate of
mittees/CommitteesMeetingMaterials/PediatricAdvisoryCommittee/ UCM204723.pdf. Accessed 2 April 2012. Data source (2002-2003): IMS Health National Prescription Audit Plus ${ }^{\mathrm{TM}}$ in briefing document from David Moeny, Pharmacist/Drug Use Specialist, Division of Surveillance, Research and Communication Support, FDA Center for Drug Evaluation and Research. Pediatric drug use analysis for topical calcineurin inhibitors, 16 July 2004. Available from http://www.fda. gov/ohrms/dockets/ac/05/briefing/2005-4089b2_01_05_Cleared\%20 version\%20Elidel-Protopic\%20Drug\%20Use\%20Review\%20D0403

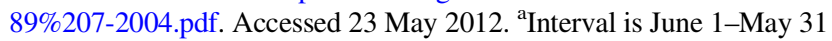

malignancy reports, and lack of evidence for systemic immune suppression with topical application of market formulations in preclinical studies. Critics also argued that the FDA overlooked the unmet medical need for these agents as an alternative to topical corticosteroids, especially for infants and patients with facial involvement [2842]. Furthermore, some members of the medical community questioned the plausibility of a biological link between immunosuppression and the types of cancers observed [4042]. On the other hand, the FDA did not rescind either drug's approval or request the termination of any of the ongoing clinical trials for either of these drugs.

\subsection{Consequences of the Boxed Warning}

As might be expected, TCI sales and off-label use among infants decreased dramatically within a year of the public health advisory (Figs. 1, 2). Payers responded to the boxed warning by creating hurdles for both healthcare providers and patients including limiting reimbursement, changing formulary status, and/or requiring pre-authorization or step-edits. Thereafter, sales of pimecrolimus cream continued to decline, possibly due to curtailed marketing efforts by Novartis. On the other hand, sales of tacrolimus ointment slightly increased despite little change in marketing efforts by Astellas. However, a survey conducted within 2 years after the labeling change reflected a negative 


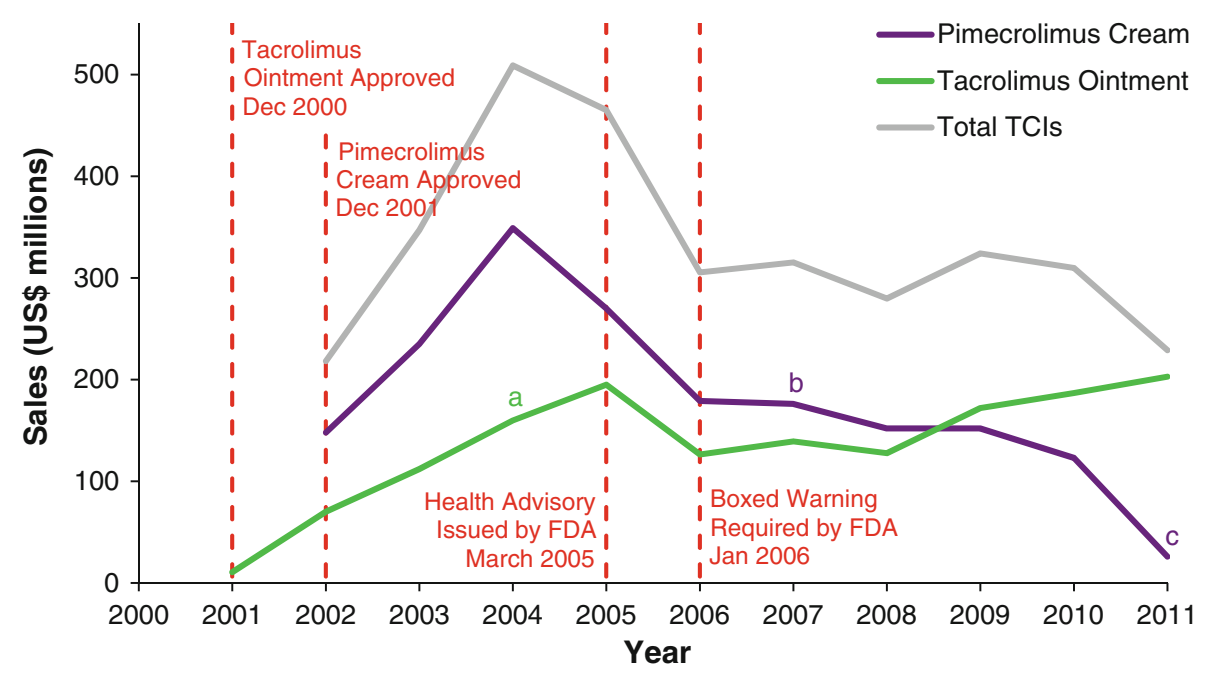

Fig. 2 Worldwide pimecrolimus cream and tacrolimus ointment sales (2000-2011). Data source for pimecrolimus cream: Novartis 2002-2003 corporate annual reports. Available from http://www unglobalcompact.org/participant/7016-Novartis-International-AG. Accessed 2 April 2012; Novartis 2004-2008 corporate annual reports. Available from http://www.novartis.com/newsroom/corporate-publi cations/archive.shtml. Accessed 2 April 2012. Elidel worldwide sales 2009-2011. Available from http://www.evaluatepharma.com/ Universal/View.aspx?type=Search\&query=elidel. Accessed 29 March

impact on long-term control among a significant minority of patients. In place of TCIs, $35 \%$ of these dermatologists prescribed chronic topical corticosteroids; $12 \%$ systemic corticosteroids; $4 \%$ cyclosporine; $4 \%$ other systemic immunosuppressants; and $20 \%$ ultraviolet (UV) B or psoralen plus UVA for AD [43].

\section{Summary of the Evidence for Lymphoma Risk}

\subsection{Preclinical Data}

At the time of approval for both drugs, malignancy signals were detected in preclinical repeat-dose and carcinogenicity studies only when systemic exposure to pimecrolimus or tacrolimus was sufficient for systemic immune suppression (Table 1) [16, 44-46]. Given the known malignancy risk with systemic immune suppressants (which increases with the intensity and duration of immune suppression) $[47,48]$, these results were not unexpected. When systemic exposure was lower (drug given to animals in their feed or topically applied using marketed formulation), there were no neoplastic findings. In human studies using topical administration (discussed in detail in Sect. 4.5.1), systemic exposure is minimal.

The most common forms of malignancy seen in transplant patients treated with systemic (oral or intravenous) tacrolimus for graph-versus-host prophylaxis are skin
2012. Data source for tacrolimus ointment: Astellas and Fujisawa 2001-2011 corporate annual reports. Available from http://www. astellas.com/en/ir/library/annual_report.html. Accessed 2 April 2012. (Using yearly conversion rates available from http://www.mac. doc.gov/japan-korea/statistics/exchange.htm. Accessed 29 March 2012.) a Fujisawa merged with Yamanouchi to become Astellas in 2004. ' Novartis promotion scaled back Q1 2007, ceased Q3 2007. ${ }^{\mathrm{c}}$ Meda acquired global rights to pimecrolimus cream Q2 2011 and immediately licensed North American rights to Valeant

carcinomas and non-Hodgkin's lymphomas (NHL) associated with Epstein-Barr virus infection, which may regress with treatment discontinuation [47]. In order to determine if systemically administered oral pimecrolimus can act through a similar mechanism, a 39-week oral (gavage) toxicity study was conducted in monkeys. The results of this study, reviewed by the FDA in February 2005 , confirmed that oral pimecrolimus, given at doses sufficient to result in systemic immune suppression $(\sim 30$ fold greater than the maximal exposure in humans with topical application), can elicit lymphomas associated with Epstein-Barr-like primate viruses similar to oral tacrolimus [49]. These results were cited as part of the basis for the boxed warning requirement for topical application $[14,50]$ despite the fact that administration was oral rather than topical and that evidence of systemic immune suppression was not detected following topical administration.

\subsection{Epidemiological Data}

The literature review considered at the March 2010 PAC meeting [51, 52] included conflicting data, summarized by Tennis et al. [53]. In comparison to untreated AD patients, Hui et al. [54] reported an increased risk of T cell lymphoma among tacrolimus ointment users (hazard ratio [95 \% CI]; 3.13 [1.41-6.94]), but not among pimecrolimus cream users [1.86 (0.71-4.87)]. On the other hand, Arellano et al. [55] found no association between TCI use 
Table 1 Relevant repeat-dose toxicity and carcinogenicity studies in animals as reviewed by the FDA (at approval)

\begin{tabular}{ll}
\hline Study Conclusions & $\begin{array}{l}\text { Systemic immune } \\
\text { suppression }\end{array}$ \\
& Malignancy findings \\
& observed? (AUC; \\
& safety margin ${ }^{\mathrm{a}}$ ) \\
\hline
\end{tabular}

\section{Tacrolimus} 80-week carcinogenicity of No relationship of tumor incidence was found No
oral (in feed) tacrolimus in CD-1 mice ${ }^{b}[16,44]$

(NA; threefold)

\begin{tabular}{|c|c|c|c|}
\hline $\begin{array}{l}\text { 104-week carcinogenicity of } \\
\text { oral (in feed) tacrolimus } \\
\text { in CD rats }{ }^{b}[16,44]\end{array}$ & No relationship of tumor incidence was found & $\begin{array}{l}\text { No } \\
\text { (NA; ninefold) }\end{array}$ & NA \\
\hline $\begin{array}{l}\text { 104-week oncogenicity of } \\
\text { topical tacrolimus } \\
\text { ointment (marketed } \\
\text { formulation) in B6C3FI } \\
\text { mice [44] }\end{array}$ & $\begin{array}{l}\text { The increased incidence of pleomorphic and } \\
\text { undifferentiated lymphomas are probably } \\
\text { due to the established pharmacologic effect } \\
\text { of tacrolimus, but the safety factor is } \\
\text { sufficient that "human patients would not } \\
\text { have a high risk" }\end{array}$ & $\begin{array}{l}\text { Yes } \\
(\sim 180 \mathrm{ng} \cdot \mathrm{h} / \mathrm{mL} ; \\
\text { tenfold })\end{array}$ & $\begin{array}{l}\text { - Topical tacrolimus ointment } 0.1 \% \text { was } \\
\text { associated with a statistically significant } \\
\text { increase in the incidence of pleomorphic } \\
\text { lymphoma (males and females) and } \\
\text { undifferentiated lymphoma (females) mostly } \\
\text { of B cell type } \\
\text { - No skin carcinomas were noted }\end{array}$ \\
\hline
\end{tabular}

Pimecrolimus [45, 46]

13-week toxicity of topical pimecrolimus in ethanol in CD-1 mice
The increased incidence of pleomorphic lymphomas observed in this study may be related to the pharmacological action of and systemic exposure to pimecrolimus
Yes; assumed
related to ethanol
vehicle

(males: $643 \mathrm{ng} \cdot \mathrm{h} /$ mL; 17-fold;

females: $675 \mathrm{ng} \cdot \mathrm{h} /$ mL; 18-fold)

\begin{tabular}{cc}
\hline $\begin{array}{c}\text { Oncogenicity of oral (gavage) } \\
\text { pimecrolimus in CD-1 }\end{array}$ & $\begin{array}{c}\text { The increased incidence of malignant } \\
\text { lymphoma was most likely a consequence of } \\
\text { mice for their life-span }\end{array}$ \\
systemic immunosuppression, but the safety
\end{tabular}
mice for their life-span

(males: 2,260 ng.h/

mL; 60-fold/

Yes

factor is "adequate" for use in humans females:

$5,059 \mathrm{ng} \cdot \mathrm{h} / \mathrm{mL}$; 133-fold)

104-week oncogenicity of
oral (gavage) pimecrolimus
in Wistar rats ( 2 replicates)

The increased incidence of benign thymoma is a significant finding but may not be relevant to humans; the safety factor for females is "adequate" for use in humans, but not for males

104-week carcinogenicity of topical pimecrolimus cream (marketed formulation) in Wistar rats ${ }^{\mathrm{c}}$
The increased incidence of follicular cell adenoma of the thyroid is a significant finding but may not be relevant to humans; the safety margin is not as great as noted in other carcinogenicity studies, but since the highest feasible dose was used, the study was considered adequate

Yes

(males: $42 \mathrm{ng} \cdot \mathrm{h} / \mathrm{mL}$;

1.1-fold/females: $805 \mathrm{ng} \cdot \mathrm{h} / \mathrm{mL}$; 21-fold)

Not clear; but no significant toxicity was noted

(57 ng.h/mL based on highest feasible dose; 1.5-fold)
NA

- Topical pimecrolimus 25 and $50 \mathrm{mg} / \mathrm{kg} / \mathrm{day}$ were associated with lymphoproliferative changes, including malignancies

- Oral pimecrolimus $45 \mathrm{mg} / \mathrm{kg} /$ day was associated with a statistically significant increase in the incidence of follicular center cell lymphoma, pleomorphic lymphoma, and combined lymphoma in both males and females

- Oral pimecrolimus $5 \mathrm{mg} / \mathrm{kg} /$ day (males) and $10 \mathrm{mg} / \mathrm{kg} /$ day (males and females) were associated with a "biologically significant" increase in the incidence of benign thymoma

- A statistically significant increase in the incidence of follicular cell adenoma in the thyroid in all topical pimecrolimus cream dose groups $(0.2,0.6$, and $1.0 \%)$ was noted in males only ${ }^{\mathrm{d}}$

- A slight (non-significant) increase in benign thymoma was seen in males at all doses and in females at the $0.2 \%$ dose level $^{\mathrm{e}}$

- Non-neoplastic minimal-to-moderate application site epithelial hyperplasia was noted for both pimecrolimus cream and vehicle; this was attributed to vehicle effects

- No lymphomas were noted

$A U C$ area under concentration-time curve, NA not available, NOAEL no observed adverse effect level

a AUC is based on NOAEL unless otherwise noted; safety margin is in comparison to highest AUC seen with topical administration in humans

b Both the mouse and rat oral (in feed) studies were deemed as inadequate because of inadequate duration and low systemic exposure; however, since these studies are heavily referenced in the FDA toxicology review, they are included in this table

c No malignancies were found in an additional 104-week carcinogenicity study of topical pimecrolimus in ethanol in CD-1 mice; however, the study was deemed unacceptable by the FDA because of inadequate high dose and is not included in this table

${ }^{\mathrm{d}}$ Male rats are more sensitive to thyroid effects than female rats or humans because of lower T4 hormone levels; this finding may not be relevant to humans

e Values fell within the historical range for Wistar rats and/or showed no dose dependence; this finding was determined to be not significant 
(pimecrolimus cream or tacrolimus ointment) and lymphoma of any type (adjusted odds ratio [95\% CI]; 0.82 [0.42-1.61] and 0.79 [0.37-1.71], respectively) compared with untreated AD patients. Schneeweiss et al. [56] also report no significant increase in risk for lymphoma of any type (rate ratio $[95 \% \mathrm{CI}]$; pimecrolimus cream: 1.79 [0.92-3.48]; tacrolimus ointment: 1.97 [0.87-4.50], respectively) nor for cutaneous lymphomas (1.49 [0.36-6.24]; 2.53 [0.51-12.6], respectively) when TCI users were compared with untreated AD patients. As with all retrospective studies, each of these reports has significant limitations, including low numbers of pediatric patients, short duration, potential association between $\mathrm{AD}$ and lymphoma, no assessment by lymphoma subtype, exclusion of a lag period, and lack of case verification.

A full report of an additional long-term study was available for the May 2011 PAC meeting [52]. This study found no evidence for increased risk of lymphoma of any type for the overall population $(625,915$ patients; adjusted odds ratio $[95 \% \mathrm{CI}]$; pimecrolimus cream: 0.76 [0.54-1.08]; tacrolimus ointment: 1.24 [0.80-1.91]) or among those patients younger than 20 years of age (396,069 patients; pimecrolimus cream: 0.64 [0.34-1.21]; tacrolimus ointment: 0.96 [0.38-2.45]) compared with untreated $\mathrm{AD}$ patients (patients were followed from 6 months to over 10 years). Among patients exposed to the highest cumulative dose of tacrolimus ointment $(\geq 0.10 \mathrm{~g})$, the risk of lymphoma was significantly increased (2.08 [1.24-3.49]); however, no association was evident for pimecrolimus cream. When $\mathrm{T}$ cell lymphomas were evaluated alone, they found an increased risk of T cell lymphoma among tacrolimus ointment users (4.95 [1.86-13.19]), which was dose-dependent $(<0.03 \mathrm{~g}: 4.27 \quad[0.24-75.49] ; \geq 0.03$ to $<0.06$ g: $5.36[0.78-37.05]$; $\geq 0.06$ to $<0.10$ g: 6.03 [1.31-27.70]; $\geq 0.10 \mathrm{~g} ; 12.76$ [3.35-48.68]). T cell lymphoma risk was not elevated among pimecrolimus cream users $(0.85$ [0.25-2.90]) and showed no dose-dependence. Dose-dependence results for $\mathrm{T}$ cell lymphoma should be interpreted with caution, however, because of the low number of cases in each category.

\subsection{Clinical Databases}

Relative cancer risk may be best appreciated by comparing the actual number of reports in the entire exposed population compared with the general population. In order to make such a comparison, the cumulative worldwide exposure was calculated by dividing the total amount (in grams) of cream or ointment sold worldwide since launch by the average amount of drug dispensed per year per patient in the USA to obtain cumulative 'patient-years' (PY) of exposure (Eq. 1). Thus, cumulative exposure, expressed as PY accounts not only for the number of patients exposed but also for duration of exposure. This method assumes constant distribution of tube sizes and number of 'fills' over time, in different countries, and for all age ranges.

$$
\begin{aligned}
& \text { Amount sold worldwide since launch }(\mathrm{g}) \\
& \text { Average amount dispensed (g/patient/year) } \\
& =\text { Cumulative exposure }(\mathrm{PY})
\end{aligned}
$$

The number of reports that would be expected in the general population (of similar age range) over the same duration of observation (PY) was calculated on the basis of age-adjusted incidences (per 100,000 PY) found in the Surveillance, Epidemiology and End Results (SEER) database (Eq. 2). In comparing these numbers, the rate of malignancies and lymphomas with TCIs observed in several clinical databases, including AERS, is similar to or lower than the rate seen in the general population (Table 2) [57-65]. In cases where only the number of exposed patients is known (e.g., sponsored clinical trials databases), and no information is available about the duration of exposure, the expected number of malignancies cannot be calculated in a manner that would allow for a comparison across different study durations.

$$
\begin{array}{r}
\frac{\text { Age-adjusted SEER incidence }}{100,000(\mathrm{PY})} \times \text { cumulative exposure }(\mathrm{PY}) \\
=\text { Expected reports }
\end{array}
$$

\section{Critical Evaluation of the Evidence}

A number of generally confounding factors must be considered when evaluating the strength of the evidence that led to the FDA decision to apply the boxed warning-the difficulty in assessing the risk of rare events, possible confounding effects of disease state and severity, and a consideration of risks and benefits across a number of alternative therapies. Confounding factors specific to this examination include the relative importance of preclinical versus clinical data and the intrinsic properties of each of the compounds.

\subsection{Inherent Difficulties in Assessing the Risk of Rare Events}

Assessing risk based on spontaneous adverse event reports (such as AERS) is complicated because of variable underreporting, indeterminate population size, and inconsistent data quality, especially for details on drug exposure and underlying diseases [66]. Spontaneous reporting might be especially problematic for adverse events with long latency times. Adverse events are believed to be under-reported to the FDA by a factor of as much as 10 and the reporting rate changes for the same product over time, with new and 
Table 2 Actual number of malignancy and lymphoma (Hodgkin's and Non-Hodgkin's) reports in clinical databases compared with the expected number of reports in the general population (based on SEER [57])

\begin{tabular}{|c|c|c|c|c|c|c|c|c|}
\hline \multirow[t]{2}{*}{ Data source } & \multirow[t]{2}{*}{$\begin{array}{c}\text { Cumulative } \\
\text { Exposure, } \mathrm{PY}^{\mathrm{a}}\end{array}$} & \multirow{2}{*}{$\begin{array}{l}\text { Age } \\
\text { Range, } \\
\text { years }\end{array}$} & \multicolumn{2}{|c|}{ Any Malignancy } & \multicolumn{2}{|c|}{$\begin{array}{l}\text { Hodgkin's Lymphoma } \\
\text { (HL) }\end{array}$} & \multicolumn{2}{|c|}{$\begin{array}{l}\text { Non-Hodgkin's } \\
\text { Lymphoma (NHL) }\end{array}$} \\
\hline & & & Actual & $\begin{array}{l}\text { Expected } \\
(95 \% \mathrm{CI})^{\mathrm{b}}\end{array}$ & Actual & $\begin{array}{l}\text { Expected } \\
(95 \% \mathrm{Cl})^{\mathrm{b}}\end{array}$ & ctual & $\begin{array}{l}\text { Expected } \\
(95 \% \mathrm{Cl})^{\mathrm{b}}\end{array}$ \\
\hline \multicolumn{9}{|l|}{ TACROLIMUS OINTMENT } \\
\hline $\begin{array}{l}\text { Sponsored Comparative Clinical Trials in AD[58] } \\
\text { (as of December 2005) }\end{array}$ & $(\sim 4,200 \mathrm{pts})$ & all ages & 0 & -- & 0 & -- & 0 & -- \\
\hline $\begin{array}{l}\text { US Post-Marketing Surveillance (PMS)[59] } \\
\text { (as of December 2009) }\end{array}$ & $\begin{array}{c}\sim 1,600,000^{\circ} \\
(\sim 927,000 \mathrm{pts})\end{array}$ & pediatric $^{d}$ & 18 & $\begin{array}{l}276 \\
(267-285)\end{array}$ & NA & -- & NA & -- \\
\hline \multirow{2}{*}{$\begin{array}{l}\text { US Post-Marketing Surveillance (PMS)[60] } \\
\text { (as of February 2005) }\end{array}$} & \multirow{2}{*}{$\begin{array}{c}\sim 3,000,000^{\mathrm{c}} \\
(\sim 1,700,000 \mathrm{pts})\end{array}$} & \multirow[b]{2}{*}{ all ages } & \multirow[b]{2}{*}{ NA } & \multirow[b]{2}{*}{-} & \multirow{2}{*}{$\begin{array}{l}\mathrm{HL} \text { and } \mathrm{NHL} \\
\text { Lymphoma }\end{array}$} & \multicolumn{3}{|c|}{ Expected $(95 \% \mathrm{Cl})^{\mathrm{b}}$} \\
\hline & & & & & & $\begin{array}{r}11 \text { (incl. } 6 \text { CTCL, } \\
0 \text { in }<16 \text { YO) } \\
\end{array}$ & $\begin{array}{l}659 \\
(646-672)^{f}\end{array}$ & \\
\hline $\begin{array}{l}\text { APPLES[61] } \\
\text { (as of September 2010) }\end{array}$ & $\begin{array}{c}10,724 \\
(5,872 \mathrm{pts})\end{array}$ & $<16$ & 2 & $\begin{array}{l}1.9 \\
(1-2)\end{array}$ & 0 & $\begin{array}{l}0.1 \\
(0-1)\end{array}$ & 0 & $\begin{array}{l}0.1 \\
(0-1)\end{array}$ \\
\hline $\begin{array}{l}\text { AERS[62] } \\
\text { (as of May 2011) }\end{array}$ & $\begin{array}{l}\sim 1,600,000^{\mathrm{c}, \mathrm{g}} \\
(\sim 927,000 \mathrm{pts})\end{array}$ & $<16$ & 22 & $\begin{array}{l}276^{\mathrm{g}} \\
(267-285)\end{array}$ & 0 & $\begin{array}{l}21^{9} \\
(18-24)\end{array}$ & $\begin{array}{r}\text { cl. } 4 \mathrm{CTCL} \\
1 \mathrm{CT} / \mathrm{BCL})\end{array}$ & $\begin{array}{l}19^{g} \\
(16-22)\end{array}$ \\
\hline \multicolumn{9}{|l|}{ PIMECROLIMUS CREAM[63] } \\
\hline $\begin{array}{l}\text { Sponsored Controlled Clinical Trials in AD } \\
\text { (as of March 2011) }\end{array}$ & (>55,000 pts) & all ages & 5 & -- & 0 & -- & 1 (CTCL) & -- \\
\hline $\begin{array}{l}\text { Worldwide Post-Marketing Surveillance (PMS) } \\
\text { (as of March 2011) }\end{array}$ & $>19,000,000$ & all ages ${ }^{i}$ & 163 & $\begin{array}{l}\mathbf{8 6 , 7 2 0} \\
(86,447-86,995)\end{array}$ & $\begin{array}{r}19 \text { (incl. } 5 \\
\text { in <20 YO) }\end{array}$ & $\begin{array}{l}508 \\
(487-530)\end{array}$ & $\begin{array}{l}\text { cl. } 8 \mathrm{CTCL} \text {, } \\
\text { in <20 YO) }\end{array}$ & $\begin{array}{l}3,663 \\
(3,606-3,721)\end{array}$ \\
\hline $\begin{array}{l}\text { PEER } \\
\text { (as of October 2011) }\end{array}$ & $\begin{array}{c}\mathbf{1 6 , 2 1 9} \\
(6,073 \mathrm{pts})\end{array}$ & $2-17$ & 2 & $\begin{array}{l}2.8 \\
(2-3) \\
\end{array}$ & 0 & $\begin{array}{l}0.2 \\
(0-1)\end{array}$ & 0 & $\begin{array}{l}0.2 \\
(0-1)\end{array}$ \\
\hline $\begin{array}{l}\text { AERS[62] } \\
\text { (as of May 2011) }\end{array}$ & $>9,000,000^{1}$ & $<16$ & 43 & $\begin{array}{l}1,554 \\
(1,506-1,602)\end{array}$ & 4 & $\begin{array}{l}119 \\
(106-134)\end{array}$ & 11 & $\begin{array}{l}106 \\
(93-119)\end{array}$ \\
\hline \multicolumn{9}{|l|}{ TACROLIMUS OINTMENT \& PIMECROLIMUS CREAM } \\
\hline $\begin{array}{l}\text { AERS[62] } \\
\text { (as of May 2011) }\end{array}$ & -- & $<16$ & 7 & -- & 0 & -- & 1 & -- \\
\hline
\end{tabular}

APPLES and PEER are the ongoing 10-year prospective registries (planned $N=8,000$ for each) designed to assess the risk of malignancies in children

$A D$ atopic dermatitis, $A E R S$ FDA's adverse event reporting system, $C I$ confidence interval, $C T C L$ cutaneous $\mathrm{T}$ cell lymphoma, $C T / B C L$ cutaneous $\mathrm{T}$ cell and B cell lymphoma, $H L$ Hodgkin lymphoma, incl. includes, $N A$ not available, $N H L$ non-Hodgkin lymphoma, $p t s$ patients, $P Y$ patientyears, $T C I$ topical calcineurin inhibitor, $Y O$ year olds, - not calculable

${ }^{\text {a }}$ Calculated by dividing the total amount (g) of cream or ointment sold worldwide since launch by the average amount of drug dispensed per year per patient (g/year/patient)

b Estimated based on age-adjusted incidences (per 100,000 PY) for 2009 (the most recent estimate available) in the SEER database [57]; estimates were rounded to the nearest whole number unless estimate was $<10$, then estimate was rounded to the nearest tenth; Lower limits of $95 \%$ confidence intervals were rounded to the next lower whole number, upper limits were rounded to the next higher whole number)

${ }^{c}$ Estimated by multiplying the approximate number of patients exposed by the factor $(3,000,000$ PY/1,700,000 patients) given in the Tacrolimus Ointment February 2005 PAC Briefing Book [64]

d Age range not further specified

e Only incidence of overall lymphoma available

${ }^{\mathrm{f}}$ Calculated by adding the expected $(95 \% \mathrm{CI}$ ) number of reports for HL and NHL to obtain expected (95\% CI) number of reports for all lymphomas

g Based on exposure data as of December 2009, the most recent estimate available

${ }^{\mathrm{h}}$ Includes clinical trial (solicited), spontaneous, and literature reports

${ }^{i}$ Actual reports were in patients ranging in age from 11 months to 70 years

${ }^{\mathrm{j}}$ Includes 13 unspecified lymphomas

${ }^{\mathrm{k}}$ Includes 4 unspecified lymphomas in patients $<20 \mathrm{YO}$

${ }^{1}$ Calculated by multiplying the cumulative exposure (PY) by the proportion of prescriptions dispensed to $<17$ YO estimated using SDI Vector One ${ }^{\circledR}$ data from 2004 to 2008 [65] (assuming that number and distribution of prescriptions were similar between 2002-2003 and 2004 and between 2009-2011 and 2008)

highly publicized drugs susceptible to increased reporting rates.

\subsection{Confounding Factors: Disease State and Severity}

The interpretation of results of studies examining risk associated with TCI exposure alone may be challenging because of several confounding factors. Namely, that $\mathrm{AD}$ like psoriasis (another inflammatory skin disease) may be independently associated with a risk of developing lymphoma, which increases with severity [53, 67-71]. On the other hand, in some cases, cutaneous $\mathrm{T}$ cell lymphoma may be misdiagnosed as $\mathrm{AD}$ (and treated as such) owing to similar clinical signs and symptoms [29, 72-74]. In 
addition, patients receiving TCIs as second-line therapy or at higher doses may bias the patient population toward more severe disease and greater exposure, thereby also increasing the potential for misleading results.

\subsection{Benefit-Risk Analysis: Considering Alternative Therapies}

In order to properly weigh the risks and benefits of $\mathrm{AD}$ treatment, one must consider the benefits and adverse effects of all possible treatments. Topical corticosteroids (TCS) are the mainstay of treatment for AD flares. However, no TCSs are indicated for long-term ( $>4$ weeks) use and few are approved for patients younger than 2 years of age [75] because of skin-thinning potential and rebound effects. TCIs, on the other hand, have low atrophogenic potential [76] and skin permeation (as discussed in Sect. 4.5.1) and can be used for long periods, even on sensitive skin areas, without risk of developing tachyphylaxis [77-86].

There are no preclinical carcinogenicity studies of TCS due to rapid toxicity in mice and rats, although, as an immune suppressant, there is a plausible link. In fact, other alternative anti-inflammatory $\mathrm{AD}$ treatments (i.e., oral corticosteroids, oral immunosuppressives, and phototherapy) all carry a risk of cancer $[42,71]$, and malignancy risk with TCS is unclear [56, 87-89].

\subsection{Sufficient Evidence for TCI Boxed Warning?}

According to FDA guidance, boxed warnings are ordinarily applied when (a) there is an adverse reaction so serious in proportion to the potential benefit from the drug (e.g., fatal, life-threatening, or permanently disabling) that it is essential that it be considered when assessing the benefitrisk ratio of prescribing the drug; (b) there is a serious adverse reaction that can be prevented or reduced in frequency or severity by appropriate use of the drug (e.g., patient selection, careful monitoring, avoiding use in a specific clinical situation); or (c) the FDA approved the drug with restrictions to ensure safe use [90]. According to the guidance, a boxed warning can also be used to highlight information that is considered especially important to the prescriber (e.g., reduced effectiveness in certain patient populations). Boxed warnings are most often based on observed serious adverse reactions (i.e., clinical data) or, in some cases, based on anticipated adverse reactions [i.e., an expected adverse reaction based on pharmacologic action of the drug (preclinical data)]. Beach et al. [91] found that over $80 \%$ of boxed warnings (in the 1995 Physicians, Desk Reference) were based on clinical data including adverse event reports obtained through clinical trials and spontaneous reports. Only $9 \%$ of warnings were based on 'other' evidence.
The boxed warning for TCIs was implemented despite the fact that "a causal relationship has not been established" $[3,16]$. While no specific risks have been identified, the label indicates that "long-term safety of topical calcineurin inhibitors has not been established....[and] rare cases of malignancy (e.g., skin and lymphoma) have been reported in patients treated with [TCIs]" $[3,16]$. In contrast, the boxed warning for long-acting $\beta$-agonists for childhood asthma is based on data from large placebocontrolled trials that showed an increase in asthma-related deaths [92].

There is some precedent for removing a boxed warning based on differences in systemic exposure between oral and topical formulations and/or new clinical data [93-95]. Given the inconclusive nature of prior evidence, the clinical value of TCIs, and the negative impact of limiting patients' access to TCIs, significant weight should be given to more recent epidemiological and clinical data when considering the ongoing need for the boxed warning.

\subsection{Justification for a Class Labeling?}

The FDA applies pharmacological classes to drugs in order to help prescribers avoid duplicative therapy and drug interactions. In order to maintain consistency, the agency considers applying warnings, contraindications, and boxed warnings to all members of a pharmacological class; however, it does allow for these to be applied to a single member of a class if the benefit-risk ratio is shown to apply to only one member [90]. Low systemic exposure with TCIs and striking differences between pimecrolimus cream and tacrolimus ointment in terms of pharmacology and clinical development programs might justify reconsideration of class labeling and/or warnings.

\subsubsection{Low Systemic Exposure}

Many studies with both pimecrolimus cream and tacrolimus ointment have shown systemic exposure to be low after topical treatment in $\mathrm{AD}$ patients as young as 3 months of age [7, 96-106]. In a head-to-head comparison study, the highest blood concentrations detected in adults with moderate-to-severe $\mathrm{AD}$ were $1.51 \mathrm{ng} / \mathrm{mL}$ in the pimecrolimus cream group and $2.39 \mathrm{ng} / \mathrm{mL}$ in the tacrolimus ointment group, both of which are substantially below target trough concentrations for systemic immunosuppression for tacrolimus $(5-20 \mathrm{ng} / \mathrm{mL})$ in transplant patients [107]. In infants, blood concentrations are similar to those seen in adults with no evidence of accumulation for up to 1 year [101-106]. The highest blood concentrations reported for infants with pimecrolimus cream $1 \%$ range from 1.8 to $4.14 \mathrm{ng} / \mathrm{mL}$ [101-105] and the average maximum 
concentration with tacrolimus ointment $0.03 \%$ was $3 \%$ of that observed in pediatric liver-transplant patients receiving oral tacrolimus [106].

In vitro skin penetration (into) for each compound is approximately equal, but skin permeation (through) is greater for tacrolimus ointment than pimecrolimus cream [108, 109]. When comparing relative permeation in normal versus inflamed or corticosteroid-pretreated skin, both compounds permeated inflamed and corticosteroid-pretreated skin to a greater extent (up to a factor of 6 times greater than normal skin) [108]. Thus, exposure to TCIs is self-limiting-as skin barrier function is restored, exposure decreases. There is also the argument that pediatric patients may have greater systemic exposure because of their greater body surface area to weight ratio. In the head-to-head trial, when blood concentrations after tacrolimus ointment application were analyzed by total body surface area (TBSA) affected by AD, they were detectable in more patients as TBSA affected by AD increased [107].

\subsubsection{Differences in Pharmacology}

Unlike tacrolimus, which was originally developed for its antirejection activity, pimecrolimus was developed specifically to target inflammatory skin diseases on the basis of its pharmacology [110]. After oral administration in rats, skin concentrations of pimecrolimus were consistently greater (twofold) than that of tacrolimus whereas in other tissues tested (blood, lymph nodes), concentrations of tacrolimus were greater (6-fold and 50-fold, respectively) [111]. In several animal models, pimecrolimus demonstrated much lower immunosuppressive potential than tacrolimus [1, 110, 112-115].

\subsubsection{Differences in Clinical Programs}

In addition, there are substantial differences in the number of patients studied (and duration of treatment) with each drug (Table 3) [63, 81, 116-118]. At the time of approval, pimecrolimus cream had been studied in more pediatric patients, including infants, for significantly longer durations, yet the indications for both drugs in these regards are remarkably similar.

\section{Implications for Daily Practice}

\subsection{Increased Burden on Medical Providers and their Patients}

Practicing physicians and their office staff bear the bulk of administrative burden generated by the boxed warning, while patients assume additional personal and financial burden. In response to the warning, third-party payers restricted off-label access to TCIs for children with conditions other than TCS-failing AD, and for all infants. Most third-party payers require time-consuming prior authorization for all TCI prescriptions. In many states, Medicaidinsured children have no access to these corticosteroidsparing medications [119] based on disease and age-specific labeling, amounting to discriminatory denials. Some physicians may be hesitant to prescribe TCIs because of a higher perceived medicolegal liability [120].

\subsection{Consequences of Inaccurate Diagnosis}

Cutaneous $\mathrm{T}$ cell lymphoma is a chronic condition with insidious onset that may be misdiagnosed as $\mathrm{AD}$, complicating assessment of a true lymphoma risk associated with TCIs.

\subsection{Consequences of Inadequate Treatment}

Active AD can have significant negative impact on quality of life for patients and their caregivers. Adequate treatment has been shown to significantly improve quality of life and patient satisfaction [121, 122]. In addition, early disease control may slow or prevent the "atopic march" to subsequent allergic rhinitis, food allergy, and asthma [123]. Suboptimal management of AD leads to more frequent flares and greater likelihood of exposure to medications like systemic corticosteroids, cyclosporine, or other immunosuppressants with higher toxicity risks [42]. And in contrast to frequent application of TCS, daily maintenance therapy with TCIs does not interfere with skin barrier integrity or enhance percutaneous absorption. Recommendations to limit exposure to topical therapy with TCIs places disproportionate importance on theoretical drug-related risks compared with well-established risks of chronic skin disease.

In addition, the costs of inadequately treated $\mathrm{AD}$ are substantial [124-127]. Dermatology is among the most difficult subspecialty to gain access to for publically insured children [128]. The frequency of emergency department (ED) visits for AD observed in one Midwest urban hospital suggests restricted access to outpatient care and suboptimal maintenance treatment, adding significant cost [119]. Emergency medicine providers receive limited training in the management of dermatological issues [119, 129]. Furthermore, prescription assistance programs (including the Allergy and Asthma Foundation, the Health Well Foundation, and the Chronic Disease Fund) do not include AD as an eligible indication.

\subsection{Optimal Use of TCIs}

Most treatment algorithms recommend regular use of emollients for control of dry skin with short-term TCS for 
Table 3 Pimecrolimus cream and tacrolimus ointment clinical development programs in atopic dermatitis
NA not applicable

${ }^{\text {a }}$ Included in total adult subjects despite overlapping age range

b Time frames differ due to data availability

${ }^{c}$ Includes duration of ongoing registry studies (APPLES and PEER); current duration of exposure is shorter

${ }^{d}$ Interim analysis

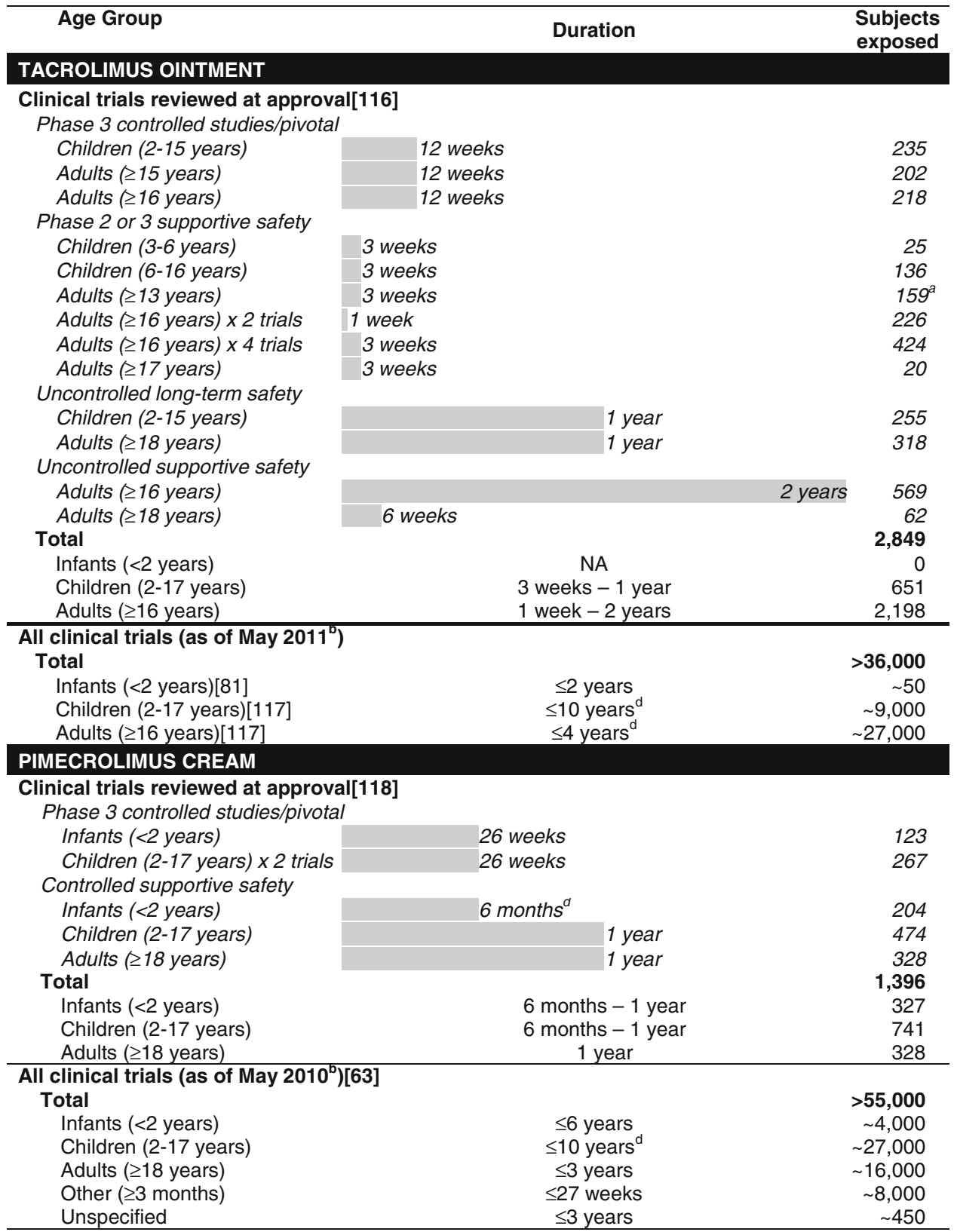

treatment of AD flares. Under certain circumstances, TCIs are a more appropriate first-line choice and/or useful adjunct to TCS.

1. As a corticosteroid-sparing agent: Reducing the risks of chronic TCS exposure is important, especially in children treated with intranasal, inhaled, or systemic corticosteroids for other atopic diseases such as asthma or allergic rhinitis. The corticosteroid-sparing effect of pimecrolimus cream has been demonstrated in clinical trials [77-79, 130-134]. A reduced number of flares and prolonged time-to-flare quantified in tacrolimus ointment clinical trials also supports a corticosteroidsparing effect [135-140].
2. To treat face and skin fold disease: Skin atrophy, perioral dermatitis, and increased percutaneous absorption are TCS risks prompting greatest concern in patients with inflammatory skin disease involving sensitive skin areas on the face, eyelids, and diaper area. TCIs are well suited for use in these areas due to low acnegenic and atrophogenic potential $[76,78,83$, 131, 141-152].

3. To simplify treatment regimens: Risks associated with TCS use are highest with more potent products, especially when applied to sensitive skin areas. To minimize these risks, a popular approach is to recommend a two-drug treatment regimen using a lower potency TCS on the face and a higher potency product on the body. Patients are 
often confused about the appropriate drug to use on the affected sites, and monitoring the optimal quantity used can also be complicated. Maintenance treatment with a TCI requires use of only one product on all affected sites. This not only simplifies treatment for the patient, but also allows easier monitoring of drug quantity used over time.

4. For children who require daily treatment: Safety of TCS has been studied for durations of no longer than 4 weeks for a limited number of products. In contrast, safety of TCIs for durations of up to 1 year has been documented in several prospective trials and registries [83-86].

5. In patients who are TCS intolerant or dependent: Well-described but under-recognized complications of long-term use of TCS include delayed-type hypersensitivity reactions, and rebound erythroderma. Neither pimecrolimus cream nor tacrolimus ointment carry these risks [150-153].

6. In patients with confirmed or suspected skin infection: 'In cognito' TCS-associated skin infections are another complication that has been well-described but underappreciated [154]. The proposed mechanism of action is via dendritic cells and antigen presentation [155]. In contrast, TCIs do not affect the differentiation, maturation, or function of dendritic cells [156-162]. Clinical trials have not identified an increased incidence of skin infection for either TCI [82, 163, 164].

\subsection{Effective Communication with Patient About the Benefit-Risk Ratio}

Even when a physician has weighed the risks and benefits and determined that TCIs are the appropriate therapy for a particular patient, an additional hurdle remains-discussing the boxed warning and medication guide. The 'real' risk of lymphoma with TCIs can be made more understandable to patients and caregivers by using some reassuring language. Suggested talking points include

1. The risk of lymphoma and other cancers is no higher than what you see in the general population.

2. TCI molecules are about twice the size of corticosteroids, which makes it more difficult for them to permeate the skin and cause systemic adverse effects.

3. All drugs, including TCIs and corticosteroids, have risks and benefits.

4. The American Academy of Dermatology (AAD) and other professional organizations do not support the boxed warning.

5. Pharmacists and other healthcare professionals may provide you with information that conflicts with what we have discussed.
6. As your physician, I have carefully weighed the risks and benefits of prescribing a TCI and feel that this drug is well suited to manage your skin condition.

\section{Conclusions}

The TCIs were a welcome therapeutic option for the management of $\mathrm{AD}$ when they were approved over 10 years ago, and they remain the only approved treatment for long-term use in children 2 years of age and older. Physicians quickly adopted the TCIs as a corticosteroidsparing adjunct to topical corticosteroids. Despite the utility of TCIs, in January 2006, the FDA implemented a boxed warning regarding the safety of long-term use and a possible risk of lymphoma and limited the indication to "second-line therapy for the short-term and noncontinuous chronic treatment of (mild-to-moderate or moderate-tosevere $\mathrm{AD})$ in nonimmunocompromised adults and children ( $\geq 2$ years of age) who have failed to respond adequately to other topical prescription treatments for (AD), or when those treatments are not advisable" $[3,16]$. This had a significant impact on physician prescribing patterns and patient access to these medications, leading to decreased disease control and quality of life for patients and their families. Many members of the medical community criticized the actions of the FDA. They questioned the validity of the boxed warning in large part because no definitive human clinical trial data has demonstrated an increased risk of malignancy with TCI exposure. In addition, several epidemiological studies have shown no association between TCI use and lymphoma risk in clinical practice, and the incidences of malignancy and lymphoma in clinical databases are below that of the general population. In addition, a possible association between AD itself and malignancy further erodes the basis for the warning. In order to provide patients with optimal care, physicians must have strategies for mitigating the impact of the boxed warning on the quality and costs of $\mathrm{AD}$ management. These include using TCIs appropriately as corticosteroidsparing agents and proactively communicating the relative risks and benefits of TCIs to patients and their caregivers.

Acknowledgments This manuscript was developed independent of any funding source. Dr. Siegfried is a full-time employee of Saint Louis University. Dr. Hebert is a full-time employee of the University of Texas Medical School at Houston. Drs. Siegfried and Hebert provided clinical perspective, guided the overall direction and content of the manuscript, and approved the final version for submission; neither received additional financial support for this work. Jennifer Jaworski, a full-time employee of Prescott Medical Communications Group (Chicago, IL, USA), drafted the manuscript at their direction and performed background research and data calculations with 
financial support from Valeant Pharmaceuticals North America LLC (Bridgewater, NJ, USA).

Dr. Siegfried has participated in contract research with Astellas Pharma US (prior to 2001) and Novartis Pharmaceuticals Corporation (prior to 2004); financial compensation for this work was paid directly to her employer. She received travel expenses related to presentation of some of this contract research from Valeant Pharmaceuticals North America LLC (in 2012). She has received consulting fees from Novartis Pharmaceuticals Corporation (prior to 2006).

Dr. Hebert has received consulting fees, been a member of speakers' bureaus, and/or served on advisory boards for Astellas Pharma US, Novartis Pharmaceutical Corporation (prior to 2008), and Valeant Pharmaceuticals North America LLC. In addition, she has participated in contract research with Astellas Pharma US and Novartis Pharmaceuticals Corporation; financial compensation for this work was paid directly to her employer. She has also served as a member of data safety monitoring boards for Valeant Pharmaceuticals North America LLC and Novartis Pharmaceuticals Corporation.

Open Access This article is distributed under the terms of the Creative Commons Attribution Noncommercial License which permits any noncommercial use, distribution, and reproduction in any medium, provided the original author(s) and the source are credited. The exclusive right to any commercial use of the article is with Springer.

\section{References}

1. Stuetz A, Baumann K, Grassberger M, et al. Discovery of topical calcineurin inhibitors and pharmacological profile of pimecrolimus. Int Arch Allergy Immunol. 2006;141(3): 199-212.

2. Protopic ${ }^{\circledR}$ (tacrolimus) ointment $0.03 \%$ and ointment $0.1 \%$ [US prescribing information]. Deerfield: Fujisawa Healthcare, Inc. 2000.

3. Elidel ${ }^{\circledR}$ (pimecrolimus) cream $1 \%$ [US prescribing information]. East Hanover: Novartis Pharmaceuticals Corporation. 2010.

4. US Department of Health and Human Services, Food and Drug Administration, Center for Drug Evaluation and Research (CDER). Protopic NDA 50-777 approval letter. December 8, 2000. http://www.accessdata.fda.gov/drugsatfda_docs/nda/2000/ 50777_Protopic_Approv.pdf. Accessed 23 Jan 2012.

5. US Department of Health and Human Services, Food and Drug Administration, Center for Drug Evaluation and Research (CDER). Elidel NDA 21-302 approval letter. December 13, 2001. http://www.accessdata.fda.gov/drugsatfda_docs/nda/2001/ 21-302_ELIDEL_Approv.pdf. Accessed 23 Jan 2012.

6. Data on file, Astellas Pharma US, 2012.

7. Krueger GG, Eichenfield L, Goodman JJ, et al. Pharmacokinetics of tacrolimus following topical application of tacrolimus ointment in adult and pediatric patients with moderate to severe atopic dermatitis. J Drugs Dermatol. 2007;6(2):185-93.

8. Margolis DJ, Hoffstad O, Bilker W. Lack of association between exposure to topical calcineurin inhibitors and skin cancer in adults. Dermatology. 2007;214(4):289-95.

9. Hanifin JM, Boguniewicz M, Eichenfield LF, et al. Long-term study of safety and allergic comorbidity development in a randomized trial of pimecrolimus cream in infants with atopic dermatitis [abstract]. J Invest Dermatol. 2010;130:S55 (Abstract 328).

10. Hanifin JM, Paller AS, Eichenfield LF, et al. The demographic profile of a large population of infants with atopic dermatitis: a longitudinal study on development of asthma and allergies [abstract]. J Am Acad Dermatol. 2007;56(Suppl 2):AB68 (Abstract P703).

11. Paller AS, Figliomeni ML, Hultsch T, et al. Efficacy and safety of pimecrolimus cream $1 \%$ in 1088 infants with atopic dermatitis: Results of the three year double-blind, vehicle controlled phase of the study of the atopic march [abstract]. Dermatitis. 2008;19(5):294-5.

12. Bishop M, Poulin Y, Qaqundah P, et al. A 5-year randomized study to investigate the safety of pimecrolimus cream $1 \%$ in the treatment of mild-to-moderate atopic dermatitis in infants: clinical safety [abstract]. J Am Acad Dermatol. 2011;64(2 Suppl 1):AB56 (Abstract P1301).

13. Poulin Y, Bishop M, Johnson A, et al. A 5-year randomized study to investigate the safety of pimecrolimus cream $1 \%$ in the treatment of mild-to-moderate atopic dermatitis in infants: immunological parameters [abstract]. J Am Acad Dermatol. 2011;64(2 Suppl 1):AB58 (Abstract P1310).

14. Briefing memorandum from Dianne Murphy, Director, Office of Pediatric Therapeutics, Office of the Commissioner, US Food and Drug Administration. February 15th, 2005 Pediatric Advisory Committee meeting on the possible risk of cancer from use of the topical immunosuppressants, February 7, 2005. http:// www.fda.gov/ohrms/dockets/ac/05/briefing/2005-4089b2_01_ 01_\%20Briefing\%20Memo.pdf. Accessed 23 Jan 2012.

15. US Food \& Drug Administration (FDA). FDA approves updated labeling with boxed warning and medication guide for two eczema drugs, Elidel and Protopic [media release]. 2006 January 19 [online]. http://www.fda.gov/Drugs/DrugSafety/Postmarket DrugSafetyInformationforPatientsandProviders/ucm153941.htm. Accessed 18 Jan 2012.

16. Protopic ${ }^{\circledR}$ (tacrolimus) ointment $0.03 \%$ and ointment $0.1 \%$ [US prescribing information]. Deerfield: Astellas Pharma US, Inc. 2011.

17. Minutes of the Pediatric Advisory Committee meeting. March 22, 2010. http://www.fda.gov/downloads/AdvisoryCommittees/ CommitteesMeetingMaterials/PediatricAdvisoryCommittee/ UCM208036.pdf. Accessed 23 Jan 2012.

18. Minutes of the Pediatric Advisory Committee meeting. May 16, 2011. http://www.fda.gov/downloads/AdvisoryCommittees/ CommitteesMeetingMaterials/PediatricAdvisoryCommittee/ UCM261384.pdf. Accessed 23 Jan 2012.

19. FDA cautions doctors on eczema treatment. Associated Press. USA Today. 2005 Mar 10.

20. Stein R. FDA considers warnings for eczema creams. Washington Post. 2005 Feb 12; Sect A: A.09.

21. Cancer warning over eczema creams. BBC News. 2005 Mar 11.

22. New warnings, risks, or restrictions for three skin drugs. ConsumerReports.org. 2005 Mar 15.

23. Elidel Lawsuits, Litigation \& Lawyers-What you should know [online]. FreeAdvice Staff. http://injury-law.freeadvice.com/ injury-law/drug-toxic_chemicals/elidel-lawsuit.htm. Accessed 8 Mar 2012.

24. Elidel and skin cancer [online]. LawyersandSettlements.com. http://www.lawyersandsettlements.com/case/elidel.html. Accessed 8 Mar 2012.

25. Elidel and the FDA 'black box' warning [online]. Awko Law. http://www.awkolaw.com/elidel/. Accessed 8 Mar 2012.

26. Eczema drugs Elidel and Protopic have been shown to cause cancer [online]. Weitz \& Luxenberg P.C. http://www.weitz lux.com/eczema-elidel-protopic-cancer_218024.html. Accessed 8 Mar 2012.

27. Elidel law suit [online]. Oshman \& Mirisola, LLP. http:// www.oshmanlaw.com/pharmaceutical_litigation/elidel.html. Accessed 8 Mar 2012.

28. Siegfried E, Silverman RA, Mancini AJ. 'Black box' warning illadvised for eczema drugs. Dermatol Times. 2006;27(3):6. 
29. Berger TG, Duvic M, Van Voorhees AS, et al. The use of topical calcineurin inhibitors in dermatology: safety concerns. Report of the American Academy of Dermatology Association Task Force. J Am Acad Dermatol. 2006;54(5):818-23.

30. Lebwohl M, Gower T. A safety assessment of topical calcineurin inhibitors in the treatment of atopic dermatitis. MedGenMed. 2006;8(4):8.

31. Thaci D, Salgo R. The topical calcineurin inhibitor pimecrolimus in atopic dermatitis: a safety update. Acta Dermatovenerol Alp Panonica Adriat. 2007;16(2):58, 60-62.

32. Orlow S. Calcineurin inhibitors and black boxes. Pediatric News. Mar 2006:24.

33. Fleischer AB Jr. Black box warning for topical calcineurin inhibitors and the death of common sense. Dermatol Online J. 2006;12(6):2.

34. Maddin S. Pimecrolimus and tacrolimus: the US FDA public health advisory. Skin Therapy Lett. 2005;10(4):1-3.

35. Canadian Dermatology Association (CDA). Position statement on topical calcineurin inhibitors [media release]. 2005 April [online]. http://www.dermatology.ca/media/position_statement/position_ topical_calcineurin_inhibitors.html. Accessed 24 Jan 2012.

36. American Academy of Dermatology (AAD). American Academy of Dermatology issues statement in response to FDA decision related to two eczema medications [media release]. 2005 March 20 [online]. http://www.thefreelibrary.com/ American+Academy+of+Dermatology+Issues+Statement+ In+Response+to+FDA-a0130070456. Accessed 5 Apr 2012.

37. Fleischer AB. Show me the signal, FDA. Skin Allergy News. May 2005:10.

38. Spergel JM, Leung DY. Safety of topical calcineurin inhibitors in atopic dermatitis: evaluation of the evidence. Curr Allergy Asthma Rep. 2006;6(4):270-4.

39. Lebwohl M. Labeling changes for the topical calcineurin inhibitors: an expert interview with Mark Lebwohl, MD. Medscape Dermatol. 2006;7(1).

40. Bieber T, Cork M, Ellis C, et al. Consensus statement on the safety profile of topical calcineurin inhibitors. Dermatology. 2005;211(2):77-8.

41. Eichenfield L. Topical pimecrolimus, tacrolimus, and the risk for cancer: an expert interview with Lawrence Eichenfield, MD. Medscape Dermatol. 2005;6(1).

42. Fonacier L, Spergel J, Charlesworth EN, et al. Report of the topical calcineurin inhibitor task force of the American College of Allergy, Asthma and Immunology and the American Academy of Allergy, Asthma and Immunology. J Allergy Clin Immunol. 2005;115(6):1249-53.

43. Ceilley R, Eisenthal A. The unintended effects of a boxed warning. J Clin Aesthet Dermatol. 2009;2(9):33-9.

44. US Department of Health and Human Services, Food and Drug Administration, Center for Drug Evaluation and Research (CDER). Protopic NDA 50-777 pharmacology review. June 19, 2000. http://www.accessdata.fda.gov/drugsatfda_docs/nda/ 2000/50777_protopic.cfm. Accessed 19 Mar 2012.

45. US Department of Health and Human Services, Food and Drug Administration, Center for Drug Evaluation and Research (CDER). Elidel NDA 21-302 pharmacology review. November 6, 2001. http://www.accessdata.fda.gov/drugsatfda_docs/nda/ 2001/21-302_Elidel.cfm. Accessed 19 Mar 2012.

46. Pediatric Advisory Committee presentation from Barbara Hill, Division of Dermatologic and Dental Drug Products, FDA Center for Drug Evaluation and Research. Topical immunosuppressants (calcineurin inhibitors)—animal toxicology. February 15,2005 . http://www.fda.gov/ohrms/dockets/ac/05/slides/ 2005-4089s2_01_06_Hill.ppt. Accessed 2 Apr 2012.

47. Prograf ${ }^{\circledR}$ (tacrolimus) capsules and injection [US prescribing information]. Deerfield: Astellas Pharma US, Inc. 2011.
48. Sandimmune ${ }^{\circledR}$ (cyclosporine) soft gelatin capsules, oral solution, and injection [US prescribing information]. East Hanover: Novartis Pharmaceuticals Corporation. 2010.

49. US Department of Health and Human Services, Food and Drug Administration, Center for Drug Evaluation and Research (CDER). Elidel NDA 21-302 pharmacokinetics/toxicokinetics review. 2005. http://www.fda.gov/ohrms/dockets/ac/05/briefing/ 2005-4089b2_01_07_Tox\%20Review\%20Redacted.pdf. Accessed 2 Apr 2012.

50. Minutes of the Pediatric Advisory Committee meeting. February 15, 2005. http://www.fda.gov/ohrms/dockets/ac/05/minutes/ 2005-4089m1_Minutes.pdf. Accessed 4 Apr 2012.

51. Briefing document from Angelika Manthripragada, Epidemiologist, Division of Epidemiology, Office of Surveillance and Epidemiology, FDA Center for Drug Evaluation and Research. Calcineurin inhibitor pediatric literature review, September 23, 2010. http://www.fda.gov/downloads/AdvisoryCommittees/ CommitteesMeetingMaterials/PediatricAdvisoryCommittee/ UCM255139.pdf. Accessed 23 Jan 2012.

52. Briefing document from Angelika Manthripragada, Epidemiologist, Division of Epidemiology, Office of Surveillance and Epidemiology, FDA Center for Drug Evaluation and Research. Addendum: Update on calcineurin inhibitor pediatric literature review, May 10, 2011. http://www.fda.gov/downloads/Advisory Committees/CommitteesMeetingMaterials/PediatricAdvisory Committee/UCM255140.pdf. Accessed 23 Jan 2012.

53. Tennis P, Gelfand JM, Rothman KJ. Evaluation of cancer risk related to atopic dermatitis and use of topical calcineurin inhibitors. Br J Dermatol. 2011;165(3):465-73.

54. Hui RL, Lide W, Chan J, et al. Association between exposure to topical tacrolimus or pimecrolimus and cancers. Ann Pharmacother. 2009;43(12):1956-63.

55. Arellano FM, Wentworth CE, Arana A, et al. Risk of lymphoma following exposure to calcineurin inhibitors and topical steroids in patients with atopic dermatitis. J Invest Dermatol. 2007; 127(4):808-16.

56. Schneeweiss S, Doherty M, Zhu S, et al. Topical treatments with pimecrolimus, tacrolimus and medium- to high-potency corticosteroids, and risk of lymphoma. Dermatology. 2009;219(1):7-21.

57. Fast Stats: An interactive tool for access to SEER cancer statistics. Surveillance Research Program, National Cancer Institute [online]. http://seer.cancer.gov/faststats. Accessed 8 Jun 2012.

58. Carroll CL, Fleischer AB Jr. Tacrolimus: focusing on atopic dermatitis. Drugs Today (Barc). 2006;42(7):431-9.

59. Pediatric Advisory Committee presentation from Seth J Orlow, Chairman \& Weinberg Professor of Pediatric Dermatology, Director, Center of Excellence in Cancers of the Skin, New York University School of Medicine. Melanocytic lesions in children and adolescents, March 22, 2010. http://www.fda.gov/ downloads/AdvisoryCommittees/CommitteesMeetingMaterials/ PediatricAdvisoryCommittee/UCM207878.pdf. Accessed 3 Apr 2012.

60. Pediatric Advisory Committee presentation from M Joyce Rico, Vice President, Medical Affairs, Astellas Pharma Global Deve lopment. Protopic ${ }^{\circledR}$ (tacrolimus) Ointment, February 15, 2005. http://www.fda.gov/ohrms/dockets/ac/05/slides/2005-4089s2_ 03_01_Fujsawa\%20FDA\%20Feb\%2015.ppt. Accessed 31 May 2012.

61. Ohtsuki M, Ohara H, Santos V, et al. Safety profiles of two large cohort studies of tacrolimus ointment for the treatment of atopic dermatitis: a prospective pediatric longitudinal evaluation study (APPLES) and japanese long-term safety study (J-LSS) [abstract]. In: Proceedings of the 22nd World Congress of Dermatology Meeting; 2011; Seoul, Korea, Poster P0327. 
62. Briefing document from Namita Kothary, Safety Evaluator, Division of Pharmacovigilance I, Office of Surveillance and Epidemiology, FDA Center for Drug Evaluation and Research. Update on Malignancies in Children, April 4, 2011. http:// www.fda.gov/downloads/AdvisoryCommittees/Committees MeetingMaterials/PediatricAdvisoryCommittee/UCM255145. pdf. Accessed 23 Jan 2012.

63. Data on file, Valeant Pharmaceuticals North America LLC, 2012.

64. Briefing book from Fujisawa Healthcare, Inc. Discussion topic: risk evaluation, labeling, risk communication, and dissemination of information on potential cancer risk among pediatric patients treated for atopic dermatitis with topical dermatological immunosuppressants, January 27, 2005. http://www.fda.gov/ ohrms/dockets/ac/05/briefing/2005-4089b2_02_02_Protopic\% 20Fujisawa\%20briefing.pdf. Accessed 6 Aug 2012.

65. Briefing document from Patty Greene, Drug Use Data Analyst, Division of Epidemiology, Office of Surveillance and Epidemiology, FDA Center for Drug Evaluation and Research. BPCA drug use review: comparison of Elidel ${ }^{\circledR}$ cream and Protopic ${ }^{\circledR}$ ointment utilization trends following 2006 labeling changes, July 17, 2009. http://www.fda.gov/downloads/AdvisoryCom mittees/CommitteesMeetingMaterials/PediatricAdvisoryComm ittee/UCM204723.pdf. Accessed 2 Apr 2012.

66. Gibbons RD, Amatya AK, Brown CH, et al. Post-approval drug safety surveillance. Annu Rev Public Health. 2010;31:419-37.

67. Arana A, Wentworth CE, Fernandez-Vidaurre C, et al. Incidence of cancer in the general population and in patients with or without atopic dermatitis in the UK. Br J Dermatol. 2010; 163(5):1036-43.

68. Margolis D, Bilker W, Hennessy S, et al. The risk of malignancy associated with psoriasis. Arch Dermatol. 2001;137(6): $778-83$.

69. Soderberg KC, Hagmar L, Schwartzbaum J, et al. Allergic conditions and risk of hematological malignancies in adults: a cohort study. BMC Public Health. 2004;4:51.

70. Hagstromer L, Ye W, Nyren O, et al. Incidence of cancer among patients with atopic dermatitis. Arch Dermatol. 2005;141(9): 1123-7.

71. Zhang Y, Holford TR, Leaderer B, et al. Prior medical conditions and medication use and risk of non-Hodgkin lymphoma in Connecticut United States women. Cancer Causes Control. 2004;15(4):419-28.

72. Miyagaki T, Sugaya M. Erythrodermic cutaneous T-cell lymphoma: how to differentiate this rare disease from atopic dermatitis. J Dermatol Sci. 2011;64(1):1-6.

73. Krol A, Krafchik B. The differential diagnosis of atopic dermatitis in childhood. Dermatol Ther. 2006;19(2):73-82.

74. Elmer KB, George RM. Cutaneous T-cell lymphoma presenting as benign dermatoses. Am Fam Phys. 1999;59(10):2809-13.

75. National Eczema Association (NEA). Topical corticosteroids: Myths \& facts [online]. http://www.nationaleczema.org/ eczema-treatments/topical-corticosteroids Accessed $2 \mathrm{Apr}$ 2012.

76. Aschoff R, Schmitt J, Knuschke P, et al. Evaluation of the atrophogenic potential of hydrocortisone $1 \%$ cream and pimecrolimus $1 \%$ cream in uninvolved forehead skin of patients with atopic dermatitis using optical coherence tomography. Exp Dermatol. 2011;20(10):832-6.

77. Wahn U, Bos JD, Goodfield M, et al. Efficacy and safety of pimecrolimus cream in the long-term management of atopic dermatitis in children. Pediatrics. 2002;110(1 Pt 1):e2.

78. Zuberbier T, Brautigam M. Long-term management of facial atopic eczema with pimecrolimus cream $1 \%$ in paediatric patients with mild to moderate disease. J Eur Acad Dermatol Venereol. 2008;22(6):718-21.
79. Kapp A, Papp K, Bingham A, et al. Long-term management of atopic dermatitis in infants with topical pimecrolimus, a nonsteroid anti-inflammatory drug. J Allergy Clin Immunol. 2002;110(2):277-84.

80. Papp KA, Werfel T, Folster-Holst R, et al. Long-term control of atopic dermatitis with pimecrolimus cream $1 \%$ in infants and young children: a two-year study. J Am Acad Dermatol. 2005;52(2):240-6.

81. Mandelin JM, Rubins A, Remitz A, et al. Long-term efficacy and tolerability of tacrolimus $0.03 \%$ ointment in infants: a twoyear open-label study. Int J Dermatol. 2012;51(1):104-10.

82. Hanifin JM, Paller AS, Eichenfield L, et al. Efficacy and safety of tacrolimus ointment treatment for up to 4 years in patients with atopic dermatitis. J Am Acad Dermatol. 2005;53(2 Suppl 2):S186-94.

83. Langley RG, Eichenfield LF, Lucky AW, et al. Sustained efficacy and safety of pimecrolimus cream $1 \%$ when used long-term (up to 26 weeks) to treat children with atopic dermatitis. Pediatr Dermatol. 2008;25(3):301-7.

84. Remitz A, Harper J, Rustin M, et al. Long-term safety and efficacy of tacrolimus ointment for the treatment of atopic dermatitis in children. Acta Derm Venereol. 2007;87(1):54-61.

85. Reitamo S, Rustin M, Harper J, et al. A 4-year follow-up study of atopic dermatitis therapy with $0.1 \%$ tacrolimus ointment in children and adult patients. Br J Dermatol. 2008;159(4):942-51.

86. Kang S, Lucky AW, Pariser D, et al. Long-term safety and efficacy of tacrolimus ointment for the treatment of atopic dermatitis in children. J Am Acad Dermatol. 2001;44(1 Suppl): S58-64.

87. Arellano FM, Arana A, Wentworth CE, et al. Lymphoma among patients with atopic dermatitis and/or treated with topical immunosuppressants in the United Kingdom. J Allergy Clin Immunol. 2009;123(5):1111-6, 116 e1-13.

88. Arana A, Wentworth CW, Rivero E, et al. Lymphoma among patients with atopic dermatitis treated with topical corticosteroids (TCS) and/or topical calcineurin inhibitors (TCIs) [abstract]. Pharmacoepidemiol Drug Saf. 2010;19:S12 (Abstract 28).

89. Arana A, Wentworth CW, Rivero E, et al. Lymphoma among patients with atopic dermatitis treated with topical corticosteroids and/or topical calcineurin inhibitors [abstract]. J Am Acad Dermatol. 2011;64(2 Suppl 1):AB3 (Abstract P203).

90. Guidance for Industry. Warnings and precautions, contraindications, and boxed warning sections of labeling for human prescription drug and biological products - content and format. US Department of Health and Human Services, Food and Drug Administration, Center for Drug Evaluation and Research (CDER) \& Center for Biologics Evaluation and Research (CBER). October 2011. http://www.fda.gov/downloads/Drugs/ GuidanceComplianceRegulatoryInformation/Guidances/ucm07 5096.pdf. Accessed 19 Mar 2012.

91. Beach JE, Faich GA, Bormel FG, et al. Black box warnings in prescription drug labeling: results of a survey of 206 drugs. Food Drug Law J. 1998;53(3):403-11.

92. Advair Diskus 100/50, 250/50, and 500/50 (fluticasone propionate $100 / 250 / 500 \mathrm{mcg}$ and salmeterol $50 \mathrm{mcg}$ inhalation powder) [US prescribing information]. Research Triangle Park: GlaxoSmithKline. 2011.

93. Metronidazole tablets USP [US prescribing information]. Corona: Watson Pharma, Inc. 2010.

94. Metronidazole gel $0.75 \%$ USP [US prescribing information]. Hawthorne: Taro Pharmaceuticals USA, Inc. 2011.

95. US Food and Drug Administration (FDA). FDA modifies boxed warning for pulmonary arterial hypertension drug Letairis [media release]. 2011 March 4, [online]. http://www.fda.gov/ NewsEvents/Newsroom/PressAnnouncements/2011/ucm245848. htm. Accessed 21 June 2012. 
96. Van Leent EJ, Ebelin ME, Burtin P, et al. Low systemic exposure after repeated topical application of Pimecrolimus (Elidel), SD Z ASM 981) in patients with atopic dermatitis. Dermatology. 2002;204(1):63-8.

97. Rubins A, Gutmane R, Valdmane N, et al. Pharmacokinetics of $0.1 \%$ tacrolimus ointment after first and repeated application to adults with moderate to severe atopic dermatitis. J Invest Dermatol. 2005;125(1):68-71.

98. Ling M, Gottlieb A, Pariser D, et al. A randomized study of the safety, absorption and efficacy of pimecrolimus cream $1 \%$ applied twice or four times daily in patients with atopic dermatitis. J Dermatolog Treat. 2005;16(3):142-8.

99. Van Leent EJ, De Vries HJ, Ebelin ME, et al. Blood concentrations of pimecrolimus in adult patients with atopic dermatitis following intermittent administration of pimecrolimus cream $1 \%$ (Elidel) for up to 1 year. J Dermatolog Treat. 2007;18(1):19-22.

100. Undre NA, Moloney FJ, Ahmadi S, et al. Skin and systemic pharmacokinetics of tacrolimus following topical application of tacrolimus ointment in adults with moderate to severe atopic dermatitis. Br J Dermatol. 2009;160(3):665-9.

101. Harper J, Green A, Scott G, et al. First experience of topical SDZ ASM 981 in children with atopic dermatitis. Br J Dermatol. 2001;144(4):781-7.

102. Lakhanpaul M, Davies T, Allen BR, et al. Low systemic exposure in infants with atopic dermatitis in a 1-year pharmacokinetic study with pimecrolimus cream 1\%. Exp Dermatol. 2006;15(2):138-41.

103. Eichenfield LF, Ho V, Matsunaga J, et al. Blood concentrations, tolerability and efficacy of pimecrolimus cream $1 \%$ in Japanese infants and children with atopic dermatitis. J Dermatol. 2007;34(4):231-6.

104. Staab D, Pariser D, Gottlieb AB, et al. Low systemic absorption and good tolerability of pimecrolimus, administered as $1 \%$ cream (Elidel) in infants with atopic dermatitis-a multicenter, 3-week, open-label study. Pediatr Dermatol. 2005;22(5): 465-71.

105. Allen BR, Lakhanpaul M, Morris A, et al. Systemic exposure, tolerability, and efficacy of pimecrolimus cream $1 \%$ in atopic dermatitis patients. Arch Dis Child. 2003;88(11):969-73.

106. Reitamo S, Mandelin J, Rubins A, et al. The pharmacokinetics of tacrolimus after first and repeated dosing with $0.03 \%$ ointment in infants with atopic dermatitis. Int $\mathrm{J}$ Dermatol. 2009;48(4):348-55.

107. Draelos Z, Nayak A, Pariser D, et al. Pharmacokinetics of topical calcineurin inhibitors in adult atopic dermatitis: a randomized, investigator-blind comparison. J Am Acad Dermatol. 2005;53(4):602-9.

108. Meingassner JG, Aschauer H, Stuetz A, et al. Pimecrolimus permeates less than tacrolimus through normal, inflamed, or corticosteroid-pretreated skin. Exp Dermatol. 2005;14(10): $752-7$.

109. Billich A, Aschauer H, Aszodi A, et al. Percutaneous absorption of drugs used in atopic eczema: pimecrolimus permeates less through skin than corticosteroids and tacrolimus. Int J Pharm. 2004;269(1):29-35.

110. Stuetz A, Grassberger M, Meingassner JG. Pimecrolimus (Elidel, SDZ ASM 981)—preclinical pharmacologic profile and skin selectivity. Semin Cutan Med Surg. 2001;20(4):233-41.

111. Schweitzer A, Figueiredo J, Zehender H, et al. Pimecrolimus (SDZ ASM 981) has higher affinity for the skin than tacrolimus (FK 506) - a tissue distribution study in rats [abstract]. J Eur Acad Dermatol Venereol. 2002;16(Suppl 1):257 (Abstract P24-27).

112. Grassberger M, Steinhoff M, Schneider D, et al. Pimecrolimus-an anti-inflammatory drug targeting the skin. Exp Dermatol. 2004;13(12):721-30.
113. Meingassner JG, Grassberger M, Fahrngruber H, et al. A novel anti-inflammatory drug, SDZ ASM 981, for the topical and oral treatment of skin diseases: in vivo pharmacology. Br J Dermatol. 1997;137(4):568-76.

114. Meingassner J, Di Padova F, Hiestand P, et al. Pimecrolimus (Elidel ${ }^{\circledR}$, SDZ ASM 981): highly effective in animal models of skin inflammation but low activity in models of immunosuppression [abstract]. J Eur Acad Dermatol Venereol. 2001;15(Suppl 2):214 (Abstract P20-25).

115. Meingassner J, Hiestand P, Bigout M, et al. SDZ ASM 981 is highly effective in animal models of skin inflammation, but has only low activity in models indicating immunosuppressive potential, in contrast to cyclosporin A and FK 506 [abstract]. J Invest Dermatol. 2001;117(2):532 (Abstract 858).

116. US Department of Health and Human Services, Food and Drug Administration, Center for Drug Evaluation and Research (CDER). Protopic NDA 50-777 medical review. June 19, 2000. http://www.accessdata.fda.gov/drugsatfda_docs/nda/2000/50777_ protopic.cfm. Accessed 23 Jan 2012.

117. Pediatric Advisory Committee presentation from Joyce Rico, Vice President, Medical Affairs, Astellas Pharma Global Development. Topical tacrolimus ointment (Protopic ${ }^{\circledR}$ ), May 16, 2011. http://www.fda.gov/downloads/AdvisoryCommittees/ CommitteesMeetingMaterials/PediatricAdvisoryCommittee/ UCM261387.pdf. Accessed 3 Apr 2012.

118. US Department of Health and Human Services, Food and Drug Administration, Center for Drug Evaluation and Research (CDER). Elidel NDA 21-302 medical review. November 6, 2001. http://www.accessdata.fda.gov/drugsatfda_docs/nda/2001/ 21-302_Elidel.cfm. Accessed 5 Apr 2012.

119. Prodanovic E, Siegfried E, Peter J. Number and cost analysis of ed admissions for atopic dermatitis [abstract]. Caribbean Dermatology Symposium; 2010 Jan 19-23; San Juan, Puerto Rico.

120. AMA House of Delegates Health and Ethics Policies. Patient access to treatments prescribed by their physicians. H-120.988 2012. https://ss13.ama-assn.org/apps/ecomm/PolicyFinderForm. pl?site=www.ama-assn.org\&uri=/ama1/pub/upload/mm/Policy Finder/policyfiles/HnE/H-120.988.HTM. Accessed 23 Jan 2012.

121. Ingram JR, Martin JA, Finlay AY. Impact of topical calcineurin inhibitors on quality of life in patients with atopic dermatitis. Am J Clin Dermatol. 2009;10(4):229-37.

122. Schiffner R, Schiffner-Rohe J, Landthaler M, et al. Treatment of atopic dermatitis and impact on quality of life: a review with emphasis on topical non-corticosteroids. Pharmacoeconomics. 2003;21(3):159-79.

123. Spergel JM, Paller AS. Atopic dermatitis and the atopic march. J Allergy Clin Immunol. 2003;112(6 Suppl):S118-27.

124. Ellis CN, Drake LA, Prendergast MM, et al. Cost of atopic dermatitis and eczema in the United States. J Am Acad Dermatol. 2002;46(3):361-70.

125. Mancini AJ, Kaulback K, Chamlin SL. The socioeconomic impact of atopic dermatitis in the United States: a systematic review. Pediatr Dermatol. 2008;25(1):1-6.

126. Lapidus CS, Schwarz DF, Honig PJ. Atopic dermatitis in children: who cares? Who pays? J Am Acad Dermatol. 1993;28(5 Pt 1):699-703.

127. Fivenson D, Arnold RJ, Kaniecki DJ, et al. The effect of atopic dermatitis on total burden of illness and quality of life on adults and children in a large managed care organization. J Manag Care Pharm. 2002;8(5):333-42.

128. Bisgaier J, Rhodes KV. Auditing access to specialty care for children with public insurance. N Engl J Med. 2011;364(24): 2324-33.

129. Wang E, Lim BL, Than KY. Dermatological conditions presenting at an emergency department in Singapore. Singap Med J. 2009;50(9):881-4. 
130. Siegfried E, Korman N, Molina C, et al. Safety and efficacy of early intervention with pimecrolimus cream $1 \%$ combined with corticosteroids for major flares in infants and children with atopic dermatitis. J Dermatolog Treat. 2006;17(3):143-50.

131. Zuberbier T, Heinzerling L, Bieber T, et al. Steroid-sparing effect of pimecrolimus cream $1 \%$ in children with severe atopic dermatitis. Dermatology. 2007;215(4):325-30.

132. Sigurgeirsson B, Ho V, Ferrandiz C, et al. Effectiveness and safety of a prevention-of-flare-progression strategy with pimecrolimus cream $1 \%$ in the management of paediatric atopic dermatitis. J Eur Acad Dermatol Venereol. 2008;22(11):1290-301.

133. Gollnick H, Kaufmann R, Stough D, et al. Pimecrolimus cream $1 \%$ in the long-term management of adult atopic dermatitis: prevention of flare progression. A randomized controlled trial. Br J Dermatol. 2008;158(5):1083-93.

134. Meurer M, Folster-Holst R, Wozel G, et al. Pimecrolimus cream in the long-term management of atopic dermatitis in adults: a six-month study. Dermatology. 2002;205(3):271-7.

135. Doss N, Kamoun MR, Dubertret L, et al. Efficacy of tacrolimus $0.03 \%$ ointment as second-line treatment for children with moderate-to-severe atopic dermatitis: evidence from a randomized, double-blind non-inferiority trial vs. fluticasone $0.005 \%$ ointment. Pediatr Allergy Immunol. 2010;21(2 Pt 1):321-9.

136. Thaci D, Chambers C, Sidhu M, et al. Twice-weekly treatment with tacrolimus $0.03 \%$ ointment in children with atopic dermatitis: clinical efficacy and economic impact over 12 months. J Eur Acad Dermatol Venereol. 2010;24(9):1040-6.

137. Reitamo S, Allsopp R. Treatment with twice-weekly tacrolimus ointment in patients with moderate to severe atopic dermatitis: results from two randomized, multicentre, comparative studies. J Dermatolog Treat. 2010;21(1):34-44.

138. Breneman D, Fleischer AB Jr, Abramovits W, et al. Intermittent therapy for flare prevention and long-term disease control in stabilized atopic dermatitis: a randomized comparison of 3 -times-weekly applications of tacrolimus ointment versus vehicle. J Am Acad Dermatol. 2008;58(6):990-9.

139. Thaci D, Reitamo S, Gonzalez Ensenat MA, et al. Proactive disease management with $0.03 \%$ tacrolimus ointment for children with atopic dermatitis: results of a randomized, multicentre, comparative study. Br J Dermatol. 2008;159(6):1348-56.

140. Wollenberg A, Reitamo S, Atzori F, et al. Proactive treatment of atopic dermatitis in adults with $0.1 \%$ tacrolimus ointment. Allergy. 2008;63(6):742-50.

141. Jensen JM, Pfeiffer S, Witt M, et al. Different effects of pimecrolimus and betamethasone on the skin barrier in patients with atopic dermatitis. J Allergy Clin Immunol. 2009;123(5): 1124-33.

142. Queille-Roussel C, Graeber M, Thurston M, et al. SDZ ASM 981 is the first non-steroid that suppresses established nickel contact dermatitis elicited by allergen challenge. Contact Dermatitis. 2000;42(6):349-50.

143. Reitamo S, Rissanen J, Remitz A, et al. Tacrolimus ointment does not affect collagen synthesis: results of a single-center randomized trial. J Invest Dermatol. 1998;111(3):396-8.

144. Kyllonen H, Remitz A, Mandelin JM, et al. Effects of 1-year intermittent treatment with topical tacrolimus monotherapy on skin collagen synthesis in patients with atopic dermatitis. Br J Dermatol. 2004;150(6):1174-81.

145. Lubbe J, Friedlander SF, Cribier B, et al. Safety, efficacy, and dosage of $1 \%$ pimecrolimus cream for the treatment of atopic dermatitis in daily practice. Am J Clin Dermatol. 2006;7(2):121-31.

146. Freeman AK, Serle J, VanVeldhuisen P, et al. Tacrolimus ointment in the treatment of eyelid dermatitis. Cutis. 2004; 73(4):267-71

147. Kang S, Paller A, Soter N, et al. Safe treatment of head/neck AD with tacrolimus ointment. J Dermatolog Treat. 2003;14(2):86-94.
148. Doss N, Reitamo S, Dubertret L, et al. Superiority of tacrolimus $0.1 \%$ ointment compared with fluticasone $0.005 \%$ in adults with moderate to severe atopic dermatitis of the face: results from a randomized, double-blind trial. Br J Dermatol. 2009;161(2): 427-34.

149. Nivenius E, van der Ploeg I, Jung K, et al. Tacrolimus ointment vs steroid ointment for eyelid dermatitis in patients with atopic keratoconjunctivitis. Eye (Lond). 2007;21(7):968-75.

150. Kawakami T, Soma Y, Morita E, et al. Safe and effective treatment of refractory facial lesions in atopic dermatitis using topical tacrolimus following corticosteroid discontinuation. Dermatology. 2001;203(1):32-7.

151. Hoeger PH, Lee KH, Jautova J, et al. The treatment of facial atopic dermatitis in children who are intolerant of, or dependent on, topical corticosteroids: a randomized, controlled clinical trial. Br J Dermatol. 2009;160(2):415-22.

152. Murrell DF, Calvieri S, Ortonne JP, et al. A randomized controlled trial of pimecrolimus cream $1 \%$ in adolescents and adults with head and neck atopic dermatitis and intolerant of, or dependent on, topical corticosteroids. Br J Dermatol. 2007; 157(5):954-9.

153. Leung DY, Hanifin JM, Pariser DM, et al. Effects of pimecrolimus cream $1 \%$ in the treatment of patients with atopic dermatitis who demonstrate a clinical insensitivity to topical corticosteroids: a randomized, multicentre vehicle-controlled trial. Br J Dermatol. 2009;161(2):435-43.

154. Hengge UR, Ruzicka T, Schwartz RA, et al. Adverse effects of topical glucocorticosteroids. J Am Acad Dermatol. 2006;54(1): 1-15 (quiz 16-8).

155. Hultsch T, Kapp A, Spergel J. Immunomodulation and safety of topical calcineurin inhibitors for the treatment of atopic dermatitis. Dermatology. 2005;211(2):174-87.

156. Kalthoff FS, Chung J, Musser P, et al. Pimecrolimus does not affect the differentiation, maturation and function of human monocyte-derived dendritic cells, in contrast to corticosteroids. Clin Exp Immunol. 2003;133(3):350-9.

157. Meingassner JG, Kowalsky E, Schwendinger H, et al. Pimecrolimus does not affect Langerhans cells in murine epidermis. Br J Dermatol. 2003;149(4):853-7.

158. Kwiek B, Peng WM, Allam JP, et al. Tacrolimus and TGF-beta act synergistically on the generation of Langerhans cells. J Allergy Clin Immunol. 2008;122(1):126-32, 132 e1.

159. Meindl S, Vaculik C, Meingassner JG, et al. Differential effects of corticosteroids and pimecrolimus on the developing skin immune system in humans and mice. J Invest Dermatol. 2009; 129(9):2184-92.

160. Schuller E, Oppel T, Bornhovd E, et al. Tacrolimus ointment causes inflammatory dendritic epidermal cell depletion but no Langerhans cell apoptosis in patients with atopic dermatitis. J Allergy Clin Immunol. 2004;114(1):137-43.

161. Krummen MB, Varga G, Steinert M, et al. Effect of pimecrolimus vs. corticosteroids on murine bone marrow-derived dendritic cell differentiation, maturation and function. Exp Dermatol. 2006;15(1):43-50.

162. Hoetzenecker W, Ecker R, Kopp T, et al. Pimecrolimus leads to an apoptosis-induced depletion of $\mathrm{T}$ cells but not Langerhans cells in patients with atopic dermatitis. J Allergy Clin Immunol. 2005;115(6):1276-83.

163. Fleischer AB Jr, Ling M, Eichenfield L, et al. Tacrolimus ointment for the treatment of atopic dermatitis is not associated with an increase in cutaneous infections. J Am Acad Dermatol. 2002;47(4):562-70.

164. Langley RG, Luger TA, Cork MJ, et al. An update on the safety and tolerability of pimecrolimus cream $1 \%$ : evidence from clinical trials and post-marketing surveillance. Dermatology. 2007;215(Suppl 1):27-44. 